\title{
RESPON PERTUMBUHAN DAN PRODUKSI JAGUNG MANIS AKIBAT PEMBERIAN BOKASHI DAN ZPT AIR KELAPA
}

\author{
Sri Handayani1, Cut Mulia Sari2 \\ 1Program Studi Agroteknologi Fakultas Pertanian \\ e-mail :s.handayani2000@gmail.com \\ 2Pengajar Prodi Agroteknologi Fakultas Pertanian, \\ e-mail :cutmuliasari@gmail.com \\ Universitas Jabal Ghafur
}

\begin{abstract}
This study aims to determine the response of growth and production of sweet corn plants due to the provision of bokashi and coconut water ZPT and the presence or absence of interaction between the two factors tested. This research was conducted in experimental garden of Faculty of Agriculture of Jabal Ghafur University Sigli from June 03 until August 08, 2017.

This research using Randomized Block Design (RAK) of factorial pattern consists of two factors, namely bokashi and ZPT Coconut Water. Each treatment was repeated 3 times, so there were 9 treatment combinations and 27 experimental units. The Bokashi (B) factor consists of: $3.6 \mathrm{~kg}$ per plot (B1), $6 \mathrm{~kg}$ per plot (B2), $8.4 \mathrm{~kg}$ per plot) (B3) and Coconut Water ZPT factor (A) consists of: $500 \mathrm{ml} /$ liter water per plot (A1), $1000 \mathrm{ml} /$ liter of water per plot (A2) and $1500 \mathrm{ml} /$ liter of water per plot (V3).

The results showed that, Bokashi and ZPT Coconut Water had no significant effect on all parameters observed and no interaction between them.
\end{abstract}

Keywords: Bokashi, ZPT Coconut Water and Sweet Corn

\section{PENDAHULUAN \\ Latar Belakang}

Tanaman jagung (Zea Mays saccaharata sturt L.) Berasal dari Amerika. Sekitar abad ke16 orang portugal menyebarluaskannya ke Asia termasuk Indonesia. Jagung merupakan bahan makanan pokok penduduk dibeberapa daerah seperti Madura dan Nusa Tenggara (Rukmana, 2009).

Di Aceh, pengembangan komoditas jagung dibeberapa kabupaten terus digalakkan ditahun ini untuk mendorong produktivitas jagung di Aceh.Pemerintah Provinsi Aceh menargetkan produksi jagung ditahun 2016 sebanyak 364.346 ton, meningkat dari sebelumnya yang hanya 187.960 ton.Kabupaten Pidie menduduki peringkat ke-5 produksi jagung tersebar di Aceh setelah Kabupaten Aceh Selatan, Aceh Utara, Aceh Besar Dan Aceh Tenggara.Sementara Kutacane (Aceh Tenggara) merupakan kabupaten penghasil jagung terbesar di Aceh, hal itu disebabkan karena jagung sudah menjadi komoditas andalan di kabupaten tersebut (Medanbisnis, 2016).

Permintaan pasar nasional dan internasional terhadap jagung manis cenderung meningkat, karena banyak Negara yang senantiasa membutuhkan dalam jumlah besar. Potensi tanaman jgung manis tiap hektarnya masih rendah sedang permintaan pasar sudah meningkat, sehingga budidaya jagung manis yang baik merupakan hal yang tepat dan mempunyai prospek pasar yang sangat bagus dimasa mendatang (Yulianti, 2010)

Dalam peningkatan produksi jagung masih manghadapi berbagai kendala, secara umum kendala teknis sering terjadi di mana penerapan komponen teknologi produksi yang belum dilakukan sesuai anjuran. Antara lain pengolahan tanah, penggunaan varietas unggul, pengairan, pengendalian hama dan penyakit, pemupukan secara tepat dan gangguan gulma serta cara bercocok tanam yang baik kurang mendapat perhatian (Adisarwanto et al., 2004).

Bokashi merupakan salah satu alternatif dalam penerapan teknologi pertanian organik yang berwawasan lingkungan dan berkelanjutan.Bokashi merupakan bahan organik yang mempunyai prospek yang baik untuk di jadikan pupuk organik (Yuliprianto, 2010).

Air kelepa merupakan bahan organik yang berguna bagi tanaman juga terdapat kandungan vitamin, asam amino, asam nukleat fosfor, zat tumbuh auksin, asam giberelat dan sitokinin yang berfungsi sebagai stimulant dalam proses perkembangan jaringan, memperlancar metabolisme dan proses respirasi, oleh karena itu air kelapa dapat membantu pembelahan sel 
dan deferensiasi sel. Sehingga mengakibatkan tanaman cepat dalam pertumbuhannya (Marsono, 2002).

Sebagaimana telah dikemukakan bahwa tanaman jagung memerlukan unsur hara dalam tanah dalam jumlah yang lebih banyak. Salah satu cara alternatif untuk memenuhi kebutuhan hara tanaman jagung yaitu dengan memberikan bokashi dan ZPT air kelapa. Sebagaimana telah diuraikan diatas bahwa, bokashi dan ZPT air kelapa merupakan bahan-bahan organik mengandung nutrisi lengkap yang dibutuhkan tanaman sehingga diharapkan dapat meningkatkan kuantitas dan kualitas produksi tanaman.Selanjutnya, muncul pertanyaan apakah penggunaan salah satu dari jenis pupuk yang ditawarkan di pasar dapat memenuhi kebutuhan hara atau tidak. Dari uraian diatas, penulis tertarik untuk mengkaji pemberian bokashi dan ZPT air kelapa terhadap pertumbuhan dan produksi tanaman jagung manis.

\section{Tujuan Penelitian}

Penelitian ini bertujuan untuk mengetahui respon pertumbuhan dan produksi tanaman jagung manisakibat pemberian bokashi dan ZPT air kelapa dan ada tidaknya interaksi antara kedua faktor yang dicobakan.

\section{Manfaat penelitian}

Hasil penelitian ini diharapkan dapat memberi manfaat dan menambah ilmu serta wawasan kepada peneliti tentang pemanfaatan bokashi dan aplikasi ZPT air kelapa sebagai unsur hara untuk tanah dan tanaman budidaya khususnya jagung sehingga mendapatkan hasil yang optimum.

\section{Rumusan Masalah}

Sejauh mana pengaruh pemberian bokashi dan ZPT air kelapa terhadap pertumbuhan dan produksi tanaman jagung manis.

\section{Hipotesis}

Di duga ada pengaruh pemberian bokashi dan pemberian ZPT air kelapa terhadap pertumbuhan dan produksi tanaman jagung manis dan interaksi anatara pemberian bokashi dan ZPT air kelapa terhadap kedua faktor tersebut.

\section{METODE PENELITIAN \\ Waktu dan Tempat Penelitian}

Penelitian ini dilaksanakan di kebun percobaan Fakultas Pertanian Universitas Jabal
Ghafur Sigli dimulai pada tanggal 03 Juni sampai dengan 08 Agustus 2017.

\section{Bahan dan Alat}

Bahan yang digunakan dalam penelitian ini adalah benih jagung manis varietas Bonanza, bokashi, air kelapa, dan pestisida.Alat-alat yang digunakan dalam penelitian ini adalah cangkul, parang, garu, tugal, tali rafia, gembor, hand spayer, meteran, karung, papan informasi, alat tulis menulis dan alat-alat lain yang mendukung penelitian ini.

\section{Rancangan Penelitian}

Penelitian ini menggunakan Rancangan Acak Kelompok (RAK) pola faktorial ada 2 faktor yang diteliti yaitu, faktor bokashi (B) ada 3 taraf dan ZPT air kelapa (A) ada 3 taraf.

Faktor pemberian Bokashi (B) terdiri dari tiga taraf yaitu :

$$
\begin{aligned}
& \mathrm{B} 1=15 \text { ton } / \mathrm{ha}(3,6 \mathrm{~kg} / \mathrm{plot}) \\
& \mathrm{B} 2=25 \text { ton } / \mathrm{ha}(6 \mathrm{~kg} / \mathrm{plot}) \\
& \mathrm{B} 3=35 \text { ton } / \mathrm{ha}(8,4 \mathrm{~kg} / \mathrm{plot})
\end{aligned}
$$

Faktor pemberian ZPT air kelapa (A) terdiri dari tiga taraf yaitu :

$\mathrm{A} 1=500 \mathrm{ml} /$ liter air per plot

$\mathrm{A} 2=1000 \mathrm{ml} /$ liter air per plot

$\mathrm{A} 3=1500 \mathrm{ml} /$ liter air per plot

Dengan demikian terdapat 9 kombinasi perlakuan dengan 3 ulangan sehingga terdapat 27 satuan percobaan.

\section{Pelaksanaan Penelitian}

Kegiatan penelitian antara lain : (1) persiapan lahan, (2)pembuatan plot, (3) penanaman, (4) pemberian bokashi, (5) aplikasi ZPT air kelapa, (6) Pemeliharaan tanaman meliputi : penyiraman, penjarangan, penyiangan, dan pengendalian hama penyakit, (7) panen

\section{Pengamatan \\ Parameter yang diamati meliputi:}

1. Tinggi Tanaman

Tinggi tanaman diukur dengan menggunakan meteran dari leher akar sampai titik tumbuh tertinggi. Pengukuran dilakukan dengan interval 10 hari sekali yaitu 10, 20, 30 dan 40 HST. Hasil pengukuran dinyatakan dalam satuan $\mathrm{cm}$.

2. Jumlah Daun

Jumlah daun diamati pada saat umur tanaman 10, 20, 30 dan 40 HST. Daun yang di hitung adalah daun yang telah sempurna.Hasil jumlah daun dinyatakan dalam satuan helai. 


\section{Panjang Tongkol}

Diukur setelah panen dengan menggunakan meteran yang diukur dari pangkal tongkol sampai ujung tongkol dinyatakan dalam satuan $\mathrm{cm}$.

\section{Berat Tongkol Per Plot}

Berat tongkol per plot dihitung dengan cara menimbang semua tongkol per plot beserta klobotnya. Hasil penimbangan berat tongkol dinyatakan dalam satuan $\mathrm{Kg}$.

\section{Produksi per Ha (Ton)}

Produksi per plot dihitung dengancara menimbang seluruh tongkol jagung pada tiaptiap plot. Penimbangan buah jagung dilakukan dengan kondisi buah jagung masih utuh, yaitu dalam kondisi seperti jagung baru dipanen dari tanamannya dan kemudian di konversikan ke Hektar (Ha).

\section{HASIL DAN PEMBAHASAN Pengaruh Bokashi}

Tinggi Tanaman

Hasil analisis ragam (Lampiran 2, 4, 6 dan 8) menunjukkan bahwa, faktor bokashi berpengaruh tidak nyata terhadap tinggi tanaman jagung manis pada umur 10, 20, 30 dan 40 HST. Rata - rata tinggi tanaman jagung manis pada umur 10, 20, 30 dan 40 HST akibat bokashi dapat dilihat pada Tabel 2 .

Tabel 2. Rata - Rata Tinggi Tanaman Jagung Manis Umur 10, 20, 30 Dan 40 HST Akibat Bokashi.

\begin{tabular}{ccccc}
\hline & \multicolumn{4}{c}{ Tinggi Tanaman $(\mathrm{cm})$} \\
\cline { 2 - 5 } Bokashi & 10 & 20 & 30 & 40 \\
& HST & HST & HST & HST \\
\hline $\mathrm{B}_{1}$ & 15,57 & 47,92 & 99,97 & 167,92 \\
$\mathrm{~B}_{2}$ & 16,63 & 46,51 & 97,04 & 168,86 \\
$\mathrm{~B}_{3}$ & 18,21 & 54,36 & 110,07 & 179,79
\end{tabular}

Pada Tabel 2 dapat dijelaskan bahwa, rata - rata tinggi tanaman jagung manis umur 10, 20, 30 dan 40 HST akibat bokashi tertinggi dijumpai pada perlakuan (B3) yaitu $18,21 \mathrm{~cm}$, $54,36 \mathrm{~cm}, 110,07 \mathrm{~cm}$ dan $179,79 \mathrm{~cm}$. Sedangkan tanaman jagung manis terendah pada umur 10 HST dijumpai pada perlakuan (B1) yaitu 15,57 $\mathrm{cm}$, umur 20 dan 30 HST dijumpai pada perlakuan (B2) yaitu $46,51 \mathrm{~cm}$ dan $97,04 \mathrm{~cm}$, serta umur 40 HST dijumpai pada perlakuan (B1) yaitu $167,79 \mathrm{~cm}$.
Faktor kekeringan mempengaruhi aspek pertumbuhan dan metabolisme tanaman termasuk integritas membran, kandungan pigmen, keseimbangan osmotik, aktivitas fotosintesis (Anjum et al,. 2011 dalam Bhardwaj dan Yadav, 2012).

Salah satu faktor yang mempengaruhi pertumbuhan awal tanaman adalah kecukupan unsur hara. Selain itu diawal fase pertumbuhan dan perkembangan tanaman, kebutuhan akan unsur hara masih sedikit sehingga hara yang tersedia didalam tanah masih mencukupi untuk mendukung pertumbuhan dan perkembangan tanaman yang optimal (Sanchez, 1992)

Jumlah daun

Hasil analisis ragam (Lampiran 10, 12, 14 dan 16) menunjukkan bahwa, faktor bokashi berpengaruh tidak nyata terhadap jumlah daun tanaman jagung manis pada umur 10, 20, 30 dan 40 HST. Rata - rata jumlah daun tanaman umur 10, 20, 30 dan 40 HST akibat pemberian bokashi dapat dilihat pada Tabel 3.

Tabel 3. Rata - rata Jumlah Daun Tanaman Jagung Manis Umur 10, 20, 30 dan 40 HST Akibat Bokashi.

\begin{tabular}{ccccc}
\hline & \multicolumn{4}{c}{ Jumlah Daun (Helai) } \\
\cline { 2 - 5 } Bokashi & 10 & 20 & 30 & 40 \\
& HST & HST & HST & HST \\
\hline $\mathrm{B}_{1}$ & 3,31 & 7,50 & 9,86 & 11,17 \\
$\mathrm{~B}_{2}$ & 3,61 & 7,51 & 9,90 & 11,95 \\
$\mathrm{~B}_{3}$ & 3,71 & 8,15 & 10,65 & 12,07 \\
\hline
\end{tabular}

Pada Tabel 3 dapat dijelaskan bahwa, rata- rata jumlah daun tanaman jagung manis umur 10, 20, 30 dan 40 HST akibat bokashi terbanyak dijumpai pada perlakuan (B3) masing - masing yaitu 3,71 helai, 8,15 helai, 10,65 helai dan 12,07 helai. Sedangkan jumlah daun terendah dijumpai pada perlakuan (B1) masing masing yaitu 3,31 helai, 7,50 helai, 9,86 helai dan 11,17 helai.

Pembentukan jumlah daun sangat ditentukan oleh jumlah dan ukuran sel, juga dipengaruhi oleh unsur hara yang diserap akar untuk dijadikan sebagai bahan makanan.Adanya unsur Nitrogen yang berfungsi sebagai penyusun enzim dan molekul khlorofil, radium berfungsi sebagai activator berbagai enzim sintesa protein maupun metabolisme karbohidrat, fosfor berperan aktif dalam mentrasfer energi di dalam sel tanaman dan magnesium sebagai penyusun 
klorofil dan membantu translokasi fosfor dalam tanaman (Latarang dan Syakur, 2006).

Panjang Tongkol

Hasil analisis ragam (Lampiran 18) menunjukkan bahwa, faktor bokashi berpengaruh tidak nyata terhadap panjang tongkol jagung manis. Rata - rata panjang tongkol jagung manis akibat bokashi dapat dilihat pada Tabel 4.

Tabel 4. Rata - Rata Panjang Tongkol Tanaman Jagung Manis Akibat Bokashi

\begin{tabular}{cc}
\hline Bokashi & Panjang Tongkol $(\mathrm{cm})$ \\
\hline $\mathrm{B}_{1}$ & 25,97 \\
$\mathrm{~B}_{2}$ & 27,84 \\
$\mathrm{~B}_{3}$ & 27,34 \\
\hline
\end{tabular}

Tabel 4 dapat menjelaskan bahwa, rata rata panjang tongkol tanaman jagung manis akibat bokashi terpanjang dijumpai pada perlakuan (B2) yaitu $27,84 \mathrm{~cm}$. Sedangkan panjang tongkol terpendek dijumpai pada perlakuan (B1) yaitu $25,97 \mathrm{~cm}$.Hal ini diduga karena faktor kekeringan sehingga bokashi lama terurai.

Fosfor dapat memperbesar pembentukan buah, selain itu ketersediaan fosfor sebagai pembentuk ATP akan terjamin ketersediaan energi bagi pertumbuhan sehingga ketersediaan asimilat dan pengangkutan ketempat penyimpanan dapat berjalan dengan baik. Hal ini menyebabkan tongkol yang dihasilkan berdiameter besar.Unsur fosfor berfungsi pada penyempurnaan tongkol serta unsur kalium juga penting untuk pengisian tongkol yaitu menjadikan tongkol berisi penuh oleh biji.Fosfor sangat mempengaruhi pembentukan tongkol (Ayunda, 2014).

Berat Tongkol Per plot

Hasil analisis ragam (Lampiran 20) menunjukkan bahwa, faktor bokashi berpengaruh tidak nyata terhadap berat tongkol per plot jagung manis. Rata - rata berat tongkol per plot jagung manis akibat bokashi dapat dilihat pada Tabel 5.

Tabel 5. Rata - Rata Berat Per Plot Tanaman Jagung Manis Akibat Bokashi

\begin{tabular}{cc}
\hline Bokashi & Berat Per Plot $(\mathrm{Kg})$ \\
\hline $\mathrm{B}_{1}$ & 4,50 \\
$\mathrm{~B}_{2}$ & 4,39 \\
$\mathrm{~B}_{3}$ & 4,48 \\
\hline
\end{tabular}

Pada Tabel 5 dapat dijelaskan bahwa, rata - rata berat tongkol per plot tanaman jagung manis akibat bokashi terberat dijumpai pada perlakuan (B1) yaitu $4,50 \mathrm{~kg}$ dan teringan dijumpai pada perlakuan (B2) yaitu 4,39 kg.

Hasil jagung manis dipengaruhi oleh Ptersedia tanah, yaitu $85 \%$ bobot tongkol jagung manis ditentukan oleh peubah tersebut dan selebihnya ditentukan oleh faktor lain (Isrun, 2006)

Produksi Per Ha

Hasil analisis ragam (Lampiran 22) menunjukkan bahwa, faktor bokashi berpengaruh tidak nyata terhadap produksi per Ha jagung manis. Rata - rata produksi per Ha jagung manis akibat bokashi dapat dilihat pada Tabel 6.

Tabel 6. Rata - Rata Produksi Per Ha Tanaman Jagung Manis Akibat Bokashi Bokashi Produksi per Ha (Ton)

\begin{tabular}{ll} 
& (Ton) \\
\hline $\mathrm{B}_{1}$ & 16,48 \\
$\mathrm{~B}_{2}$ & 16,07 \\
$\mathrm{~B}_{3}$ & 16,40 \\
\hline
\end{tabular}

Pada Tabel 6 dapat dijelaskan bahwa, rata - rata produksi per Ha tanaman jagung manis akibat bokashi terberat dijumpai pada perlakuan (B1) yaitu 16,48 Ton dan teringan dijumpai pada perlakuan (B2) yaitu 16,07 Ton.

Pemberian pupuk organik berpengaruh terhadap perkembangan tanaman yaitu berat tongkol per plot karena pupuk organik yang sesuai diberikan ketersediaan akan unsur hara telah mencukupi untuk mendukung pertumbuhan dan produksi tanaman jagung manis (Baharsyah, 2001).

\section{Pengaruh ZPT Air Kelapa}

Tinggi Tanaman

Hasil analisis ragam (Lampiran 2, 4, 6 dan 8) menunjukkan bahwa, faktor ZPT air kelapa berpengaruh tidak nyata terhadap tinggi tanaman jagung manis pada umur 10, 20, 30 dan 40 HST. Rata - rata tinggi tanaman jagung manis pada umur 10, 20, 30 dan 40 HST akibat ZPT air kelapa dapat dilihat pada Tabel 7. 
Tabel 7. Rata - rata Tinggi Tanaman Jagung Manis Umur 10, 20, 30 dan 40 HST Akibat ZPT Air Kelapa

\begin{tabular}{|c|c|c|c|c|}
\hline \multirow{3}{*}{$\begin{array}{l}\text { ZPT Air } \\
\text { Kelapa }\end{array}$} & \multicolumn{4}{|c|}{ Tinggi Tanaman $(\mathrm{cm})$} \\
\hline & 10 & 20 & 30 & 40 \\
\hline & HST & HST & HST & HST \\
\hline $\mathrm{A}_{1}$ & 16,91 & 49,92 & 103,78 & 175,64 \\
\hline $\mathrm{A}_{2}$ & 16,95 & 49,57 & 101,34 & 170,54 \\
\hline $\mathrm{A}_{3}$ & 16,54 & 49,30 & 101,96 & 170,39 \\
\hline
\end{tabular}

Pada Tabel 7 dapat dijelaskan bahwa, rata - rata tinggi tanaman jagung manis umur 10 HST akibat ZPT air kelapa tertinggi dijumpai pada perlakuan (A2) yaitu $16,95 \mathrm{~cm}$. Sedangkan tanaman jagung manis terendah dijumpai pada perlakuan (A3) yaitu $16,54 \mathrm{~cm}$. Pada umur 20, 30 dan 40 HST akibat ZPT air kelapa tertinggi dijumpai pada perlakuan (A1) yaitu 49,92 cm, $103,78 \mathrm{~cm}$ dan $175,64 \mathrm{~cm}$. Sedangkan tanaman jagung manis umur 20 HST akibat ZPT air kelapa terendah dijumpai pada perlakuan (A3) yaitu 49,30 cm. Umur 30 HST akibat ZPT air kelapa terendah dijumpai pada perlakuan (A2) yaitu 101,34 $\mathrm{cm}$ dan umur 40 HST akibat ZPT air kelapa terendah dijumpai pada perlakuan (A3) yaitu $170,39 \mathrm{~cm}$.

Wayah, dkk. (2004) bahwa jika kebutuhan air tidak dipenuhi maka pertumbuhan tanaman akan terhambat, karena air berfungsi melarutkan unsur hara dan membantu proses metabolisme dalam tanaman termasuk juga tanaman jagung.

Kandungan auksin dan sitokinin yang terdapat dalam air kelapa mempunyai peranan penting dalam proses pembelahan sel sehingga membantu pembentukan tunas dan pemanjangan batang. Auksin akan memacu sel untuk membelah secara cepat dan berkembang menjadi tunas dan batang (Pamungkas et al, 2009). Hormon tumbuh dalam air kelapa mampu meningkatkan pertumbuhan tanaman hingga 20 $-70 \%$ (Suryanto, 2009).

Jumlah daun

Hasil analisis ragam (Lampiran 10, 12, 14 dan 16) menunjukkan bahwa, faktor ZPT air kelapa berpengaruh tidak nyata terhadap jumlah daun tanaman jagung manis pada umur 10, 20, 30 dan 40 HST. Rata - rata jumlah daun umur 10, 20, 30 dan 40 HST akibat pemberian ZPT air kelapa dapat dilihat pada Tabel 8.
Tabel 8. Rata - Rata Jumlah Daun Tanaman Jagung Manis Umur 10, 20, 30 Dan 40 HST Akibat ZPT Air Kelapa

\begin{tabular}{ccccc}
\hline \multirow{2}{*}{$\begin{array}{c}\text { ZPT Air } \\
\text { Kelapa }\end{array}$} & \multicolumn{4}{c}{ Jumlah Daun (Helai) } \\
\cline { 2 - 5 } & 10 & 20 & 30 & 40 \\
& HST & HST & HST & HST \\
\hline $\mathrm{A}_{1}$ & 3,61 & 7,58 & 10,31 & 11,89 \\
$\mathrm{~A}_{2}$ & 3,56 & 7,89 & 10,20 & 11,63 \\
$\mathrm{~A}_{3}$ & 3,45 & 7,68 & 9,90 & 11,68 \\
\hline
\end{tabular}

Pada Tabel 8 dapat dijelaskan bahwa, rata - rata jumlah daun tanaman jagung manis umur 10 HST akibat ZPT air kelapa terbanyak dijumpai pada perlakuan (A1) yaitu 3,61 helai. Sedangkan jumlah daun terendah dijumpai pada perlakuan (A3) yaitu 3,45 helai. Pada umur 20 HST akibat ZPT air kelapa terbanyak dijumpai pada perlakuan (A2) yaitu 7,89 helai. Sedangkan jumlah daun terendah dijumpai pada perlakuan (A1) yaitu 7,58 helai. Pada umur 30 dan 40 HST akibat ZPT air kelapa terbanyak dijumpai pada perlakuan (A1) yaitu 10,31 helai dan 11,89 helai. Sedangkan jumlah daun terendah umur 30 HST akibat ZPT air kelapa terendah dijumpai pada perlakuan (A3) yaitu 9,90 helai dan umur 40 HST akibat ZPT air kelapa terendah dijumpai pada perlakuan (A2) yaitu 11,63 helai.

Pertumbuhan tanaman termasuk didalamnya tinggi tanaman dan jumlah daun, terjadi karena adanya proses - proses pembelahan sel dan pemanjangan sel (Kastono, 2005).

Panjang Tongkol

Hasil analisis ragam (Lampiran 18) menunjukkan bahwa, faktor ZPT air kelapa berpengaruh tidak nyata terhadap panjang tongkol jagung manis. Rata - rata panjang tongkol jagung manis akibat ZPT air kelapa dapat dilihat pada Tabel 9.

Tabel 9. Rata - Rata Panjang Tongkol Tanaman Jagung Manis Akibat ZPT Air Kelapa

\begin{tabular}{cc}
\hline ZPT Air Kelapa & $\begin{array}{c}\text { Panjang } \\
\text { Tongkol }(\mathrm{cm})\end{array}$ \\
\hline $\mathrm{A}_{1}$ & 27,94 \\
$\mathrm{~A}_{2}$ & 26,96 \\
$\mathrm{~A}_{3}$ & 26,25 \\
\hline
\end{tabular}

Pada Tabel 9 dapat dijelaskan bahwa, rata - rata panjang tongkol tanaman jagung manis 
akibat ZPT air kelapa terpanjang dijumpai pada perlakuan (A1) yaitu $27,94 \mathrm{~cm}$. Sedangkan panjang tongkol yang terpendek dijumpai pada perlakuan (A3) yaitu $26,25 \mathrm{~cm}$.

Pada konsentrasi tertentu ZPT dapat memacu pertumbuhan tanaman, tetapi pada konsentrasi yang lebih tinggi justru dapat menghambat pertumbuhan, meracuni, bahkan dapat mematikan tanaman. Oleh karena itu, penelitian uji konsentrasi ZPT pada berbagai jenis tanaman memang penting dilakukan dalam rangka meningkatkan pertumbuhan tanaman berbagai jenis tanaman memang penting dilakukan dalam rangka meningkatkan pertumbuhan tanaman secara optimal. Setiap jenis jenis tanaman memiliki kecendrungan memilih konsentrasi ZPT tertentu yang optimal bagi pertumbuhannya (Budiyanto et al, 2013).

Berat Tongkol Per plot

Hasil analisis ragam (Lampiran 20) menunjukkan bahwa, faktor ZPT air kelapa berpengaruh tidak nyata terhadap berat tongkol per plot jagung manis. Rata - rata berat tongkol per plot jagung manis akibat ZPT air kelapa dapat dilihat pada Tabel 10.

Tabel 10. Rata - Rata Berat Per Plot Tanaman Jagung Manis Akibat ZPT Air Kelapa

ZPT Air Kelapa Berat Per Plot (Kg)

\begin{tabular}{ll}
\hline $\mathrm{A}_{1}$ & 4,73 \\
$\mathrm{~A}_{2}$ & 4,33 \\
$\mathrm{~A}_{3}$ & 4,30 \\
\hline
\end{tabular}

Pada Tabel 10 dapat dijelaskan bahwa, rata - rata berat tongkol per plot tanaman jagung manis akibat ZPT air kelapa terberat dijumpai pada perlakuan (A1) yaitu 4,73 $\mathrm{kg}$ dan teringan dijumpai pada perlakuan (A3) yaitu 4,30 kg. Air kelapa mengandung komposisi kimia dan nutrisi yang lengkap (hormon, unsur hara makro, dan unsur hara mikro), sehingga apabila diaplikasikan pada tanaman akan berpengaruh positif pada tanaman (Permana, 2010).

\section{Produksi Per Ha}

Hasil analisis ragam (Lampiran 22) menunjukkan bahwa, faktor ZPT Air Kelapa berpengaruh tidak nyata terhadap produksi per Ha jagung manis. Rata - rata produksi per Ha jagung manis akibat ZPT Air Kelapa dapat dilihat pada Tabel 11.
Tabel 11. Rata - Rata Produksi Per Ha Tanaman Jagung Manis Akibat ZPT Air Kelapa

\begin{tabular}{cc}
\hline ZPT Air Kelapa & $\begin{array}{c}\text { Produksi per Ha } \\
\text { (Ton) }\end{array}$ \\
\hline $\mathrm{A}_{1}$ & 17,33 \\
$\mathrm{~A}_{2}$ & 15,87 \\
$\mathrm{~A}_{3}$ & 15,75 \\
\hline
\end{tabular}

Pada Tabel 11 dapat dijelaskan bahwa, rata - rata produksi per Ha tanaman jagung manis akibat ZPT air kelapa terberat dijumpai pada perlakuan (A1) yaitu 17,33 Ton dan teringan dijumpai pada perlakuan (A3) yaitu 15,75 Ton.

\section{Pengaruh Interaksi Bokashi dan ZPT Air Kelapa}

Hasil analisis ragam (Lampiran 2, 4, 6, 8, $10,12,14,16,18,20,22)$ menunjukkan bahwa, tidak terdapat interaksi antara bokashi dan ZPT air kelapa terhadap semua parameter yang diamati. Hal ini diduga kombinasi yang digunakan kurang tepat. Selanjutnya Apriin (2008) menyatakan bahwa, pertumbuhan dan produksi tanaman akan lebih baik bila faktor yang mempengaruhi pertumbuhan dan produksi seimbang dan memberi keuntungan, bila faktor ini tidak dapat dikendalikan maka produksi yang diharapkan tidak dapat diperoleh.

\section{PENUTUP}

\section{Kesimpulan}

1. Bokashi tidak berpengaruh nyata terhadap tinggi tanaman, jumlah daun, panjang tongkol, bobot tongkol per plot dan produksi per Ha.

2. ZPT Air Kelapa tidak berpengaruh nyata terhadap tinggi tanaman, jumlah daun, panjang tongkol, bobot tongkol per plot dan produksi per Ha.

3. Tidak terdapat interaksi yang nyata antara bokashi dan ZPT air kelapa terhadap semua parameter yang di amati.

\section{DAFTAR PUSTAKA}

Adisarwanto, T. dan Widyiastuti, Y.E. 2004.Meningkatkan Produksi Jagung di Lahan Kering Sawah Dan Pasang Surut. Penebar Swadaya. Jakarta.

Anjum, S.A., X.Y. Xie., L.C.Wang., M.F. Salem., C. Man., \& W. Lei. 2011. Morphological, Physiological, and 
Biochemical Responses of Plants to Drought Stress. African J. of Agric. Res. 6(9): $2026-2032$.

Apriin, B. 2008. Pengaruh berat umbi bibit dan dosis pup[uk KCL terhadap pertumbuhan dan produksi kentang. Skripsi. Fakultas Pertanian USU. Medan..

Ayunda, N. 2014. Pertumbuhan Dan Hasil Tanaman Jagung Manis (Zea mays saccharata Sturt.) Pada Beberapa Konsentrasi Sea minerals. Skripsi Fakultas Pertanian Universitas Taman Siswa. Padang

Baharsyah. 2001. Peranan Pupuk Organik. Penebar Swadaya. Jakarta

Bhardwaj, J., \& S.K. Yadav. 2012. Comparative Study on Biochemical Parameters and Antioxidant Enzymes in a Drought Tolerance and a Sensitive Variety of Horsegram (Macrotyloma uniflorum) Under Drought Stress. American J. Of Plant Physiol. 7(1):17 - 29

Budiyanto, M. I., Ahmad, A., dan Suhartono. 2013. Pertumbuhan Stek Cabe Jamu ( Piper Retrofractum. Vahl) Pada Berbagai Campuran Media Tanam Dnam Dan Konsentrasi ZatKonsentrasi Zat Pengatur Pengatur Tumbuh Rootone- F. Vol. 6 : 2.2 .

Isrun. 2006. Pengaruh Dosis Pupuk P Dan Pupuk Bokashi Terhadap Pertumbuhan Dan Hasil Jagung Manis (Zea mays var. Saccharata Sturt) Pada Inceptisols Jatinagor. J. Agrisains, 7 No. 1:9-17.

Kastono, D. 2005. Tanggapan Pertumbuhan Dan Hasil Kedelai Hitam Terhadap Penggunaan Pupuk Organic Dan Biopestisida Gulma Siam.

Latarang, B. dan A. Syakur. 2006. Pertumbuhan Dan Hasil Bawang Merah (Alium
Escalonicum L) Pada Berbagai Dosis Pupuk Kandang . J. Agroland. 13 (3) : 265-269.

Marsono. 2002. Kandungan unsur hara dalam air kelapa. Sinar baru. Bandung

Medan bisnis. 2016. Target produksi jagung http//mdn.biz.id/n155158/ Diakses tanggal 23 Oktober 2016

Permana, S. B. 2010. Efektifitas Konsentrasi Dan Frekuensi Pemberian Teh Kompos Limbah Kulit Kopi Dan Air Kelapa Dalam Meningkatkan Keberhasilan Bunga Kakao Menjadi Buah. Fakultas Pertanian. Universitas Jember. Jember.

Rukmana, R., 2009. Usaha Tani Jagung. Kanisius. Jakarta.

Sanchez, P. A. 1992. Sifat dan Pengelolaan Tanah Tropika.Penerbit ITB Bandung.

Suryanto, E. 2009. Air Kelapa Dalam Media Kultur Anggrek. (online). (http://wawaorchid.wordpress.com/2009 .html). Di akses 11 Mei 2017

Wayah, E., Sudiarso.,\& R. Soelistyono. 2014. Pengaruh Pemberian Air Dan Pupuk Kandang Sapi Terhadap Pertumbuhan Dan Hasil Tanaman Jagung Manis (Zea mays Saccharata Sturt L.). Jurnal Produksi Tanaman, 2 (2): 94-102

Yulianti, D., 2010. Pengaruh Hormon Organik dan Pupuk Organik Cair (POC) Super Nasa Terhadap Produksi Tanaman Jagung Manis (Zea mays saccharata Sturt). http://penelitian-organikpenelitian.blogspot.com/2010/03/pengar uh-hormon-organik-dan-pupuk.html. Diakses tanggal 20 Februari 2017

Yulipriyanto, H. 2010. Biologi Tanah dan Strategi Pengelolaannya.Graha ilmu.Yogyakarta. 